\title{
PENGARUH MINYAK ZAITUN (OLIVE OIL) TERHADAP KERUSAKAN INTEGRITAS KULIT PADA PASIEN DM TIPE II DI KECAMATAN PAGAR MERBAU
}

\section{KARDINA HAYATI ${ }^{1}$, HANA SETIANI MUTIARA ${ }^{2}$, DEWI AGUSTINA ${ }^{3}$, TAHAN ADRIANUS MANALU ${ }^{4}$, KUAT SITEPU5}

\section{1,2,3,5 INSTITUT KESEHATAN MEDISTRA LUBUK PAKAM}

Jl. Sudirman No. 38 Lubuk Pakam Kab. Deli Serdang - Sumatera utara

${ }^{4}$ Akademi Keperawatan Wira Husada Medan

Email : dina actionresearch@yahoo.com

DOI: $10.35451 / j k f . v 3 i 1.455$

\begin{abstract}
The success of changing the damage to the integrity of the skin in patients with Diabetes Mellitus Type II depends not only on early detection, but also on understanding the causative mechanism. One condition that can cause damage to the integrity of the skin was the xerosis and pruritus on skin. The purpose of this study to determine the effect of Oil Olive to damage the integrity of the skin in patients with DM type II in the District of Pagar Merbau. This type of research uses the Quasy Experiment Method using the One-Group Pretest-Posttest Design research design. Determination of the sample was done by purposive sampling, with a total sample of 22 people. Data analysis was performed using Paired Sample T Test with 95\% confidence interval and a $=0.05$. The results of this study indicate the change in damage to the integrity of the skin before and after given a basting oil olives with a $p$-value = 0.000 ( $a>0.05$ ). Conclusion, there was an influence of olive oil on damage to skin integrity in patients with type II DM in Pagar Merbau District which was carried out in accordance with standards. For Health Institutions the need for supervision and counseling to the community that the importance of maintaining skin health especially in patients with diabetes mellitus in Pagar Merbau District
\end{abstract}

Keywords : Olive Oil , Skin Integrity Damage , Type II DM patients

\section{Pendahuluan}

Penyakit Diabetes Melitus (DM) memiliki beberapa tanda dan gejala yang khas, gejala Diabetes Melitus yang khas sering disebut triaspoli yaitu terdiri dari rasa haus yang berlebihan (polidipsi), sering kencing dimalam hari (poliuri), sering merasa lapar (polipagi). Tanda dan gejala lain yang sering dialami pasien diabetes melitus ialah berat badan yang turun dengan cepat, keluhan lemah, kesemutan pada tangan dan kaki, pengelihatan kabur, impotensi, luka sulit sembuh, keputihan dan pruritus (IDF, 2017).

Berdasarkan data dari World Health Organization (WHO), 2017 didapatkan bahwa jumlah pasien Diabetes Melitus telah menyerang 415 juta orang di dunia pada tahun 2017, jumlah ini 
diperkirakan meningkat menjadi 642 juta $(55 \%)$. Diabetes Melitus menjadi kasus kematian terbesar ketiga di Indonesia sebesar $6,7 \%$, setelah stroke (21.1) dan PJK (12,9\%). Bila tidak ditanggulangi, akan menurunkan produktivitas distabilitas, kematian dini. Data Riskesdes memaparkan terjadinya kenaikan prevalensi Diabetes di Indonesia dari 5,7\% tahun 2013 menjadi $6,9 \%$ atau sekitar 9,1 juta untuk tahun 2017. Jumlah penderita diabetes melitus di Sumatera Utara setiap tahunnya mengalami kenaikan. Menurut data Dinas Kesehatan Provinsi Sumatera Utara, mulai bulan Januari 2017 hingga dengan April 2017 angka kejadian Diabetes kategori 1 sebesar 18.358 pasien dan kategori 2 sebesar 54.843 orang. Penderita diabetes melitus di Deli Serdang mencapai angka kejadian 2.275 kasus pada tahun 2018 (RISKESDAS, (2018).

Jumlah penderita diabetes melitus yang didapatkan dari data Rekam Medis Puskesmas Pagar Merbau pada tahun 2019 mencapai angka (372 kasus) dan yang mengalami kerusakan integritas kulit pada bulan November Januari 2020 dengan jumlah 93 kasus.

Pada pasien Diabetes Melitus adanya gangguan sirkulasi darah menyebabkan terganggunya sirkulasi jaringan dan kekurangan oksigen yang menyebabkan kematian jaringan tersebut. Sehingga apabila terjadi ekskorelasi pada suatu area di tubuh

\section{METODE}

Penelitian ini adalah jenis penelitian Quasy eksperimen. Penelitian dilaksanakan di wilayah kerja UPT. Puskesmas Pagar Merbau pada bulan Januari - Juli tahun 2020. Populasi penelitian yaitu seluruh pasien DM yang mengalami kerusakan integritas kulit sebanyak 93 responden. Sampel pada penelitian ini diambil secara purposive pasien diabetes melitus akibat kegiatan menggaruk hal ini dapat bertambah parah seperti menjadi luka yang tidak kunjung sembuh. Salah satu metode perawatan kulit yang dapat digunakan untuk meningkatkan proses perawatan kulit adalah dengan mempertahankan kelembaban pada dasar luka untuk mencegah kolonisasi bakteri (Tohiroh, S, 2017).

Kerusakan integritas kulit gatal atau pruritus yang disebabkan oleh mengeringnya kulit (gangguan pada regulasi tubuh) yang membuat kulit mudah luka dan gatal. Cairan tubuh yang kental, dan sirkulasinya terhambat, akibatnya energi panas meningkat (damp-heat) menyebabkan timbulnya iritasi di kulit. Gatal menimbulkan sensasi yang tidak menyenangkan yang memicu keinginan untuk menggaruk. Kegiatan menggaruk yang dilakukan terus menerus mengakibatkan terjadinya inflamasi sel dan pelepasan histamin oleh ujung saraf yang memperberat rasa gatal (Mahendra, et.al, 2016).

Menurut WHO pada tahun 2017 terdapat 1.5 juta penduduk yang mengalami kerusakan integritas kulit akibat DM. Menurut IDF (International Diabetes Federation) tahun 2018 prevalensi dengan penderita DM yang mengalami kerusakan integritas kulit mencapai 4,5 juta kasus.

sampling dengan jumlah sampel sebanyak 22 responden. Variabel independen adalah minyak zaitun (Olive Oil), variabel dependen adalah kerusakan integritas kulit. Instrumen yang digunakan adalah lembar observasi, SOP (Standar Oprasional Prosedur), minyak zaitun. Pengolahan data dilakukan melalui tahapan editing, coding, tabulasi, prosesing, dan cleaning (Notoatmodjo, S., 2012). 
Analisa data dilakukan secara deskriptif dan analisa bivariat melalui uji Paired Sampel T-Test.

\section{HASIL}

Tabel 1 Distribusi Frekuensi dan Persentase berdasarkan Tindakan pengolesan Minyak Zaitun (Olive Oil) terhadap kerusakan integritas kulit pada pasien DM tipe II di Kecamatan Pagar Merbau tahun 2020.

Sebelum pemberian intervensi pengolesan Minyak Zaitun (Olive oil)

\begin{tabular}{|c|c|c|c|}
\hline No & $\begin{array}{c}\text { Kerusakan } \\
\text { integritas } \\
\text { kulit } \\
\end{array}$ & $\mathbf{f}$ & $\%$ \\
\hline 1 & $\begin{array}{l}\text { Tidak } \\
\text { terdapat } \\
\text { kulit kering }\end{array}$ & 0 & 0 \\
\hline 2 & $\begin{array}{l}\text { Kulit kering } \\
\text { dan kusam } \\
\text { minimal }\end{array}$ & 5 & 22,7 \\
\hline 3 & $\begin{array}{l}\text { Sisik halus- } \\
\text { sedang } \\
\text { kulit } \\
\text { keputihan }\end{array}$ & 5 & 22,7 \\
\hline 4 & $\begin{array}{l}\text { Sisik kasar } \\
\text { terdistribusi } \\
\text { seragam, } \\
\text { kulit kasar } \\
\text { tampak } \\
\text { jelas }\end{array}$ & 7 & 31,8 \\
\hline \multirow[t]{2}{*}{5} & $\begin{array}{l}\text { Didominasi } \\
\text { skuama } \\
\text { kasar }\end{array}$ & 5 & 22,7 \\
\hline & Jumlah & 22 & 100,0 \\
\hline
\end{tabular}

Berdasarkan hasil penelitian pada tabel 1 tentang Pengaruh Minyak Zaitun terhadap kerusakan integritas kulit pada pasien DM tipe II di Kecamatan Pagar Merbau tahun 2020. Berdasarkan data sebelum tindakan intervensi pengolesan minyak zaitun diketahui bahwa sebanyak 7 orang $(31,8 \%)$ responden mengalami sisik kasar terdistribusi seragam, kulit kasar tampak jelas, sebanyak 5 orang $(22,7 \%)$ responden mengalami sisik halus - sedang kulit keputihan, dan masing masing sebanyak 5 orang $(22,7 \%)$ responden mengalami kulit kering, kusam minimal, dan didominasi skuama kasar. Tidak ada (0\%) responden yang mengalami kulit tidak terdapat kulit kering.

Tabel 2 Distribusi Frekuensi dan Persentase berdasarkan Tindakan pengolesan Minyak Zaitun (Olive Oil) terhadap kerusakan integritas kulit pada pasien DM tipe II di Kecamatan Pagar Merbau tahun 2020.

Setelah pemberian intervensi pengolesan Minyak Zaitun (Olive oil)

\begin{tabular}{|c|c|c|c|}
\hline No & $\begin{array}{c}\text { Kerusakan } \\
\text { integritas } \\
\text { kulit }\end{array}$ & $\mathbf{f}$ & $\%$ \\
\hline 1 & $\begin{array}{l}\text { Tidak } \\
\text { terdapat } \\
\text { kulit kering }\end{array}$ & 8 & 36,4 \\
\hline 2 & $\begin{array}{l}\text { Kulit kering } \\
\text { dan kusam } \\
\text { minimal }\end{array}$ & 5 & 22,7 \\
\hline 3 & $\begin{array}{l}\text { Sisik halus- } \\
\text { sedang } \\
\text { kulit } \\
\text { keputihan }\end{array}$ & 6 & 27,3 \\
\hline 4 & $\begin{array}{l}\text { Kulit kasar } \\
\text { terdistribusi } \\
\text { seragam, } \\
\text { kulit kasar } \\
\text { tampak } \\
\text { jelas }\end{array}$ & 3 & 13,6 \\
\hline 5 & $\begin{array}{l}\text { Didominasi } \\
\text { skuama } \\
\text { kasar }\end{array}$ & 0 & 0 \\
\hline & Jumlah & 22 & 100,0 \\
\hline
\end{tabular}


kulit pada pasien DM tipe II di Kecamatan Pagar Merbau tahun 2020. Berdasarkan data setelah tindakan intervensi pengolesan minyak zaitun diketahui bahwa sebanyak 8 orang $(36,4 \%)$ responden tidak terdapat kulit kering, sebanyak 6 orang $(27,3 \%)$ responden mengalami sisik halussedang kulit keputihan, sebanyak 5 orang $(22,7 \%)$ responden mengalami kulit kering dan kusam minimal, sebanyak 3 orang $(13,6 \%)$ responden mengalami kulit kasar terdistribusi seragam, kulit kasar tampak jelas dan sebanyak $0 \%$ responden tidak mengalami kulit didominasi skuama kasar.

\section{Pengaruh minyak zaitun (Olive Oil) terhadap kerusakan integritas kulit}

Berdasarkan hasil analisa terhadap kerusakan integritas kulit di Kecamatan Pagar Merbau sebelum dan setelah dilakukan pemberian intervensi pengolesan minyak zaitun, dengan nilai mean 2,5455 dan setelah diberikan intervensi pengolesan minyak zaitun sebanyak 8 kali dalam 2 minggu dengan nilai mean 1,1818 Berdasarkan jumlah skor masing-masing dimensi pada tabel diatas kemudian dilakukan analisa uji statistik dengan metode uji Paired Sample T-Test didapatkan indeks P-Value $=0,000<(0,05)$. Hal ini menunjukkan bahwa ada pengaruh minyak zaitun (Olive Oil) terhadap Kerusakan Integritas Kulit pada pasien DM tipe II di Kecamatan Pagar Merbau Tahun 2020.

\section{PEMBAHASAN}

Menurut hasil penelitian yang dilakukan oleh Adilinia Dewi, dkk (2017) menunjukan bahwa perawatan kulit dengan menggunakan Minyak Kelapa (Virgin Coconut Oil) terhadap penurunan rasa gatal pada pasien Diabetes Melitus, dengan dilakukan intervensi tersebut yang mengalami penurunan rasa gatal ringan sebanyak
21 responden $(63,6 \%)$, tidak gatal sebanyak 9 reponden $(27,3 \%)$, dan rasa gatal sedang sebanyak 3 responden $(6,1 \%)$. Penelitian lain yang telah dilakukan Fatimah Khoirini (2018) menunjukkan bahwa jel Lidah Buaya dalam mengurangi pruritus dengan hasil ada perbedaan yang signifikan nilai pruritus sebelum dan sesudah pemberian jel lidah buaya selama 3 hari dengan uji $t$ dependen didapat hasil nilai pruritus ( $p$ value $0,000<a=$ 0,05).

Berdasarkan penelitian yang dilakukan, maka peneliti berpendapat bahwa tindakan sebelum pemberian pengolesan minyak zaitun terdapat 22 responden dengan kategori responden mengalami sisik kasar terdistribusi seragam sebanyak 7 orang $(31,8 \%)$, sisik halus - sedang kulit tampak keputihan sebanyak 5 orang $(22,7 \%)$, responden yang mengalami kulit kusam minimal sebanyak 5 orang $(22,7 \%)$ dan responden yang mengalami kulit didominasi skuama kasar sebanyak 5 orang dan setelah dilakukan pemberian pengolesan minyak zaitun kategori responden tidak terdapat kulit kering sebanyak 8 orang $(36,4 \%)$, sisik halus - sedang kulit keputihan sebanyak 6 orang $(27,3 \%)$, kulit kering dan kusam minimal sebanyak 5 orang $(22,7 \%)$, responden yang mengalami kulit kasar terdistribusi seragam kulit kasar tampak jelas sebanyak 3 orang $(13,6 \%)$ dan tidak ada responden yang mengalami kulit didominasi skuama kasar di Kecamatam Pagar Merbau Tahun 2020.

Para ahli mencatat angka kejadian kerusakan integritas kulit pada pasien DM tipe 2 terdapat $60 \%$ terjadi kerusakan integritas kulit dikarenakan perubahan saraf dan pembuluh darah yang mengakibatkan terjadinya pruritus dan xerosis. Maka dari itu untuk menjaga kulit sebagai salah satu perawatan kulit dibutuhkan pelembab 
sebagai dasar mempertahankan Faktor Kelembaban Alami (Natural Moisture Faktor) pada kulit, membantu mempertahankan cairan pada lapisan kulit, dan mencegah hilangnya cairan seiring terjadinya kerusakan kulit (Bently, 2016).

Menurut hasil penelitian didapatkan bahwa perubahan kerusakan integritas kulit pada pasien DM tipe II di Kecamatan Pagar Merbau dengan kategori tidak terdapat kulit kering sebanyak 8 orang $(36,4 \%)$, sisik halus - sedang kulit keputihan sebanyak 6 orang $(27,3 \%)$, kulit kering dan kusam minimal sebanyak 5 orang $(22,7 \%)$, responden yang mengalami kulit kasar tampak jelas sebanyak 3 orang $(13,6 \%)$ dan tidak ada responden yang mengalami kulit didominasi skuama kasar.

Penderita diabetes melitus sering mengalami gangguan sirkulasi dalam darah dikarenakan adanya peningkatan kadar guala darah sehingga dapat menyebabkan penumpukan NonEnzymatic Glication (NEG), dan penurunan enzimatik didalam kolagen kulit hal ini yang menyebabkan pasien mengalami kulit kering dan gatal. Adapun kegiatan menggaruk yang dilakukan penderita diabetes melitus dikarenakan terjadinya inflamasi sel dan pelepasan histamine oleh ujung saraf yang dapat memperberat rasa gatal sehingga menimbulkan sensai yang tidak menyenangkan yang akan memicu keinginan untuk menggaruk. Untuk mengatasi hal tersebut dibutuhkan perawatan pada kulit agar tetap lembab dan terawat sehingga tidak menyebabkan keparahan kerusakan integritas kulit pada penderita diabetes melitus, maka peneliti menggunakan bahan alami seperti minyak zaitun (Olive Oil) yang diberikan pada sore hari dikarenakan proses pelepasan hormon melatonin terjadi pada saat malam hari, hormon melatonin sebagai salah satu proses pembentukan sel kulit (Alivn Rinaldo, Linda Julianti Wijayadi, Sari Maryati Dewi, 2019).

Menurut hasil penelitian yang dilakukan Susilo (2016) penanganan utama untuk melindungi kulit untuk mencegah kerusakan kulit dengan menggunakan Skin Cleanser (pembersi kulit) dan pelembab. Namun, adapun efek samping dan komplikasi yang terjadi jika menggunakan pelembab yang tidak alami seperti Body Lotion, ada beberapa dikalangan masyarakat yang tidak cocok menggunakan Body Lotion sehingga makin menimbulkan rasa gatal, panas dan memerah hingga kulit mengalami penipisan yang dapat terjadi dari beberapa hari hingga beberapa bulan sehingga dibutuhkan perawatan kulit dengan menggunakan bahan alami.

Menurut asumsi penelitian yang dilakukan Nuniek, dkk (2015) hasil penelitian ini menunjukan adanya perubahan kerusakan integritas kulit setelah diberikan pemberian minyak zaitun didapatkan 8 responden (53,3\%) tidak mengalami kerusakan integritas kulit dan 7 penderita $(46,7 \%)$ yang masih mengalami kerusakan integritas kulit.

Berdasarkan dua studi kasus di iran, ekstrak minyak zaitun dilaporkan sangat efektif untuk perawatan kerusakan integritas kulit, dan dalam studi eksperimental semu yang dilakukan di Mesir, hasilnya menunjukan keefektifan pengolesan minyak zaitun pada pertolongan pertama kerusakan integritas kulit. Penelitian ini bertujuan unuk menilai efek minyak zaitun topikal dalam memperbaiki kerusakan integritas kulit pada pasien DM sebagai studi uji klinis untuk menemukan pendekatan baru dalam pertolongan pertama pada kerusakan integritas kulit (Zahra A., dkk, (2015). Hasil uji statistik pired 
sample T-Test diperoleh nilai indeks $p$ Value sebesar $=0,000$ artinya hipotesa alternatif $(\mathrm{Ha})$ diterima sehingga ada Pengaruh Minyak Zaitun (Olive Oil) Terhadap kerusakan integritas kulit pada pasien DM tipe II di kecamatan Pagar Merbau.

\section{KESIMPULAN}

1. Rerata responden sebelum diberikan intervensi pengolesan minyak zaitun (Olive Oil) 2,5455 dan setelah diberikan intervensi pengolesan minyak zaitun (Olive Oil) 1,1818.

\section{DAFTAR PUSTAKA}

Alivn Rinaldo, Linda Julianti Wijayadi, Sari Maryati Dewi, (2019). Karakteristik Kadar Hidrasi Kulit Kajian Terhadap Pruritus. Tarumanegara Medival Journal Vol.1, No. 2, 245-253, april 2019.

Chaerunisa. (2017). Efektifitas Minyak Zaitun untuk Pencegahan Kerusakan Integritass Kulit pada Pasien Kusta. Nuniek Nizamah Fajriyah Journal Ilmiah Kesehatan Vol. VII. No. 1 Maret 2018.

Ginting, M. U. (2019). Uji Skripsi Mutu Minyak Zaitun Extra Virgin Olive Oil (Oleum Olivarum) yang Beredar di Medan Supermarket. Fakultas Farmasi Repositori Institusi Universitas Sumatera Utara http//repositori.usu.ac.id

Hasil Utama Riskasdas 2018 Kementrian Kesehatan Badan Penelitian dan Perkembangan Kesehatan. (2018). RISKESDAS

IDF (International Diabetes Federation) , (2018)

Mahendra et, a. (2016). Care Your Self Diabetes Melitus. Jakarta: Penebar Plus.

Notoatmodjo, S. (2012). Metodologi Penelitian Kesehatan. Jakarta: Renika Cipta.

Orey. (2013). Khasiat Minyak Zaitun. Jakarta: PT. Mizan Publika.
2. Mayoritas responden sebelum diberikan intervensi pengolesan minyak zaitun (Olive Oil) mengalami Sisik kasar terdistribusi seragam, kulit kasar tampak jelas pada kulit sebanyak 7 orang $(31,8 \%)$

3. Mayoritas responden setelah diberikan intervensi pengolesan minyak zaitun (Olive Oil) responden tidak mengalami kulit kering sebanyak 8 orang $(36,4 \%)$

Organization, W. H. (2018). Colaborative Framework for Care and Control of Diabetes. PERKENI Konsesus pengelolahan dan pencegahan diabetes melitus tipe 2 .

RISKESDAS. (2018). Hasil Utama Riskesdas 2018 Kementrian Kesehatan Badan Penelitian dan Pengembangan Kesehatan. Kementrian Kesehatan, 1-126.

RSUD Deli Serdang. Jurnal Muara Sains, Teknologi, Kedokteran dan Ilmu Kesehatan Vol. 3, No. 2, Oktober 2019: hlm 259-266.

Statistika, B. P. (2019). Katalog Kecamatan Pagar Merbau Dalam Angka 2019 ISBN; 978-6020714-26-4. Kabupaten Deli Serdang: BPS Kaupaten Deli Serdang. CV Rilis Grafika.

Susilo. (2016). Khasiat Minyak Zaitun (Olive Oil) dalam Meninngkatkan Kadar HDL (High Density Lipoprotein) Darah . Skripsi Bagian Patologi Klinik Fakultas Kedokteran Universitas Jember. Halaman 18-23.

Tohiroh, S. (2017). Skripsi Penerapan Perawatan Luka dengan Menggunakan Madu dan Minyak Zaitun pada Pasien Diabetes Melitus dengan Kerusakan Integritas Jaringan. Gombong.

UPT.Puskesmas Pagar Merbau, (2019) Data Rekam Medik.Profil Kesehatan Pagar Merbau

Zahra Abbas Ali Madadi, Reza Zeighami, Jalil Azimian, Amir 
Jurnal Keperawatan dan Fisioterapi (JKF), e-ISSN 2655-0830

Vol. 3 No.1 Edisi Mei - Oktober 2020

https://ejournal.medistra.ac.id/index.php/JKF

Received: 03 September 2020 :: Accepted: 19 September 2020 :: Published: 31 Oktober 2020

Javadi. (2015). The Effect of Topical Olive Oil on Prevention of Bedsore in Intensive Care Units Patients. International Journal of
Research in Medical Sciences pISSN 2320-6071/ eISSN 23206012 . 